\title{
МАТЕМАТИЧНІ МОДЕЛІ РОЗПОДІЛУ ГУСТИНИ СТРУМУ ВИСОКОЇ ЧАСТОТИ В ЕЛЕКТРОДАХ 3 РІЗНИМИ ФОРМАМИ ПОПЕРЕЧНОГО ПЕРЕРІЗУ
}

Дубко А.Г., с.н.с., к.т.н andreyies17@gmail.com Відділ «Зварювальні та споріднені технології в медицині та екології» Інституту електрозварювання імені Є.О. Патона НАН України, м. Київ, Україна

Чвертко Н.А., с.н.с. , к.т.н chv@paton.kiev.ua

Відділ «Зварювальні та споріднені технології в медицині та екології» Інституту електрозварювання імені Є.О. Патона НАН України, м. Київ, Україна

Лебедєв О.В., проф., д.т.н. biowelding@gmail.com Факультет біомедичної інженерії Національного технічного університету «Київський політехнічний інститут імені Ігоря Сікорського», м. Київ, Україна

Подпрятов С.С., К.м.н. sspjdpr@gmail.com Київська міська клінічна лікарня №1, м. Київ, Україна

Нікітін В.О., студент viktor070200@gmail.com Кафедра біомедичної інженерії Національного технічного університету «Київський політехнічний інститут імені Ігоря Сікорського», м. Київ, Україна

Реферат - У середовищі математичного пакета Маtlab зроблений аналіз розподілу щуільності високочастотного струму в електродах електрохірургічних інструментів. Представлені результати розрахунків одновимірної $i$ двомірних задач, які моделюють товщину скін-ефекту в провідниках з різною формою поперечного перерізу. Запропоновані нові конструктивні форми електродів для високочастотної хірургї̈, які дають можливість рівномірно розподілити струм по їх контактним поверхням.

Ключові слова - струми високої частоти, форми поперечного перерізу електродів, математичне моделювання, скін-ефект, розподіл густини струму, Матлаб.

\section{I. ВСТУП}

Важливим і затребуваним в медичній практиці $€$ рішення прикладних задач пов'язаних з використанням струмів високої частоти в електрохірургії при коагуляції [1-2] і зварюванні [3] живих біологічних тканин.

Різні форми поперечного перерізу електродів електрохірургічних інструментів показані на рисунках 1-8.

Використання математичних методів моделювання при проектуванні нових електрохірургічних

технологій

та інструментів, які знижують перегрівання живих біологічних тканин i їх некроз, представляє наукову новизну і практичний інтерес. Відомо [4], що проходження високочастотного струму через провідне середовище викликає нерівномірний розподіл густини струму (скін-ефект) в поперечному перерізі цього середовища. Це явище необхідно враховувати при розробці електрохірургічних інструментів. Дія скінефекту проявляється при приварюванні 
відшарованої сітківки до судинної оболонки ока [5]. Ця робота проводиться в Інституті очних хвороб і тканинної терапії ім. В. П. Філатова АМН України спільно з Інститутом електрозварювання ім. Є. О. Патона.

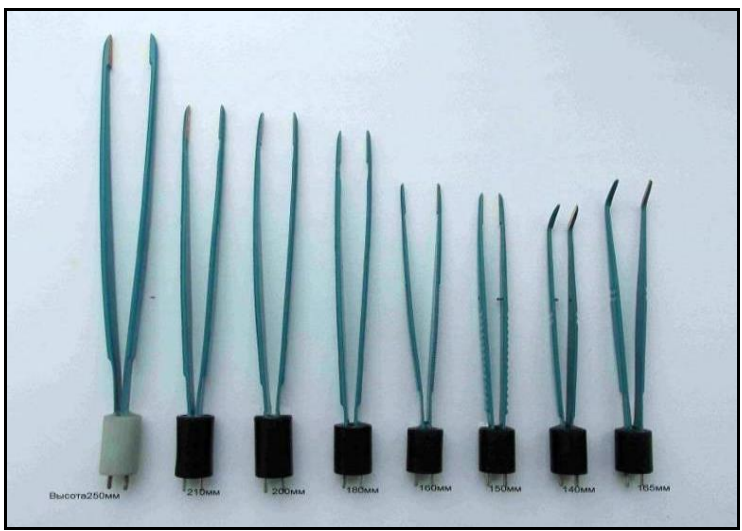

Рис. 1. Електрохірургічні пінцети.

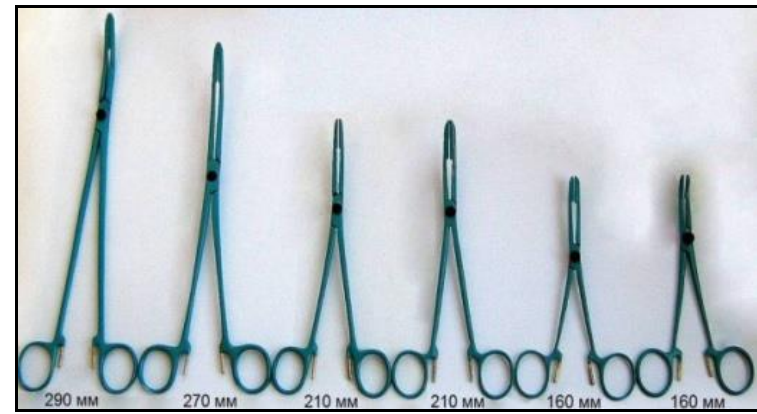

Рис. 2. Електрохірургічні затискачі.

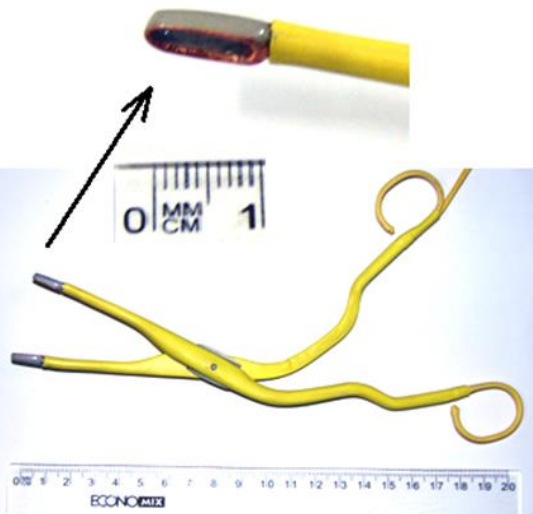

Рис. 3. Електрохірургічний інструмент для оториноларингології.

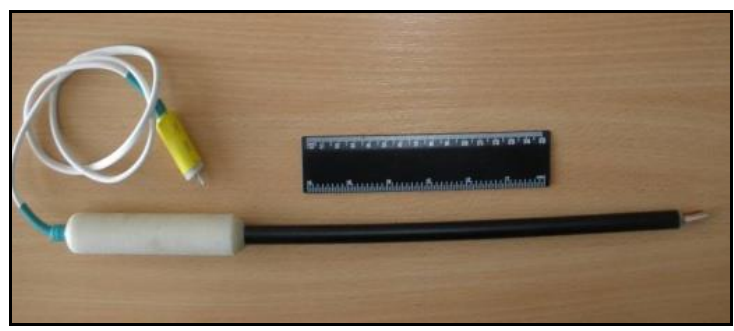

Рис. 4. Електрохірургічний інструмент для торокальних операцій.

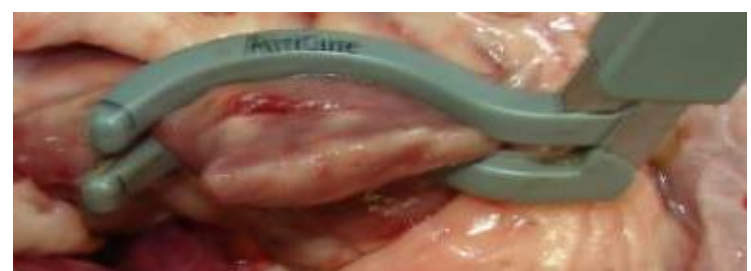

Рис. 5. Електрохірургічний інструмент для абляції тканин серця.

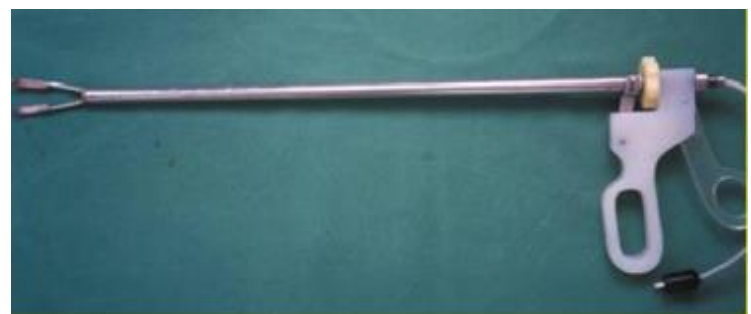

Рис. 6. Електрохірургічний інструмент для лапароскопічних операцій.

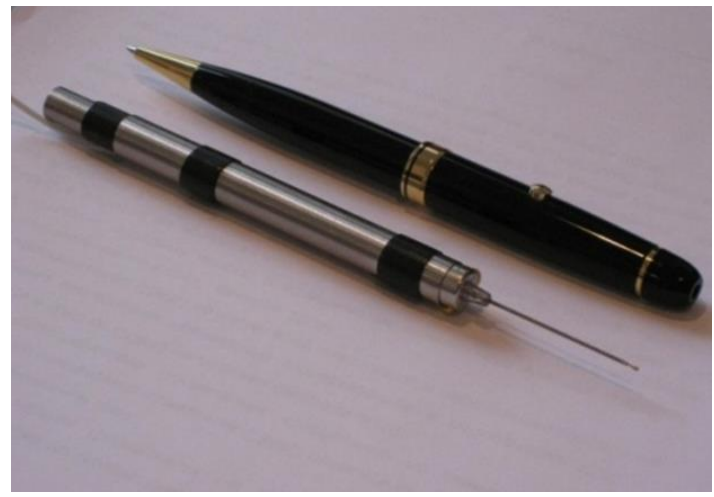

Рис. 7. Електрохірургічний інструмент для приварювання відшарованої сітківки ока до судинної оболонки ока.

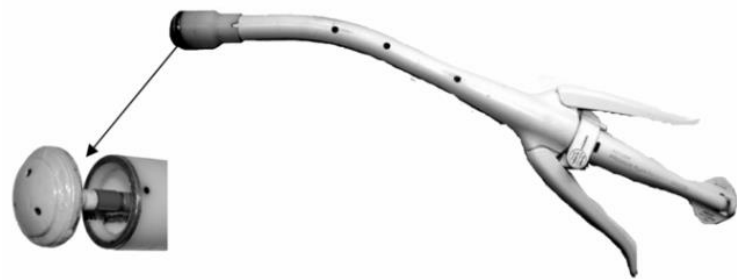

Рис. 8. Електрохірургічний інструмент для операцій на кишці.

Загальній теорії проходження змінного струму через циліндричний провідник присвячена робота [6], але в ній йдеться про розробку вимірювальних приладів на низьких частотах. В роботі [7] моделюється проходження струму при електрохірургічних втручаннях, але не враховується дія скінефекту.

Проаналізувати електромагнітні процеси в електродах можливо за допомогою рівнянь математичної фізики, що 
представляють собою диференціальні рівняння в приватних похідних. Чисельні методи розв'язання практичних завдань детально викладені в роботах $[8,9]$.

\section{META}

Основна мета проведення досліджень аналіз розподілу густини струму в електродах 3 різними формами поперечного перерізу 3 урахуванням скін-ефекту.

\section{III. РЕЗУЛЬТАТИ ТА ОБГОВОРЕННЯ}

В середовищі математичного пакету Matlab [10], за допомогою методу кінцевих різниць проведено аналіз електромагнітних процесів в електродах електрохірургічних інструментів 3 різною формою поперечного перерізу.

\section{Електрофізичні}

провідних середовищ електрохірургічних характеристики (електродів інструментів) визначаються їх питомою електропровідністю $\boldsymbol{\sigma}$, діелектричною $\boldsymbol{\varepsilon}$ i магнітною $\boldsymbol{\mu}$ проникністю. Змінне електромагнітне поле описується рівнянням, яке витікає 3 рівнянь Максвела [11].

$$
-\nabla\left(\frac{1}{\mu} \nabla E\right)+\left(j \omega \sigma-\omega^{2} \varepsilon\right) E=0
$$

де $\nabla$ - оператор набла;

E - напруженість електромагнітного поля;

$\omega$ - кутова частота;

$\mathrm{j}$ - уявна одиниця.

В результаті досліджень показано, що в мідному круглому електроді (радіус електрода $\left.0,33 \mathrm{Mм}, \quad \sigma=57 \cdot 10^{6} \mathrm{CM} / \mathrm{M}\right)$ на частотах 66 кГц та $1 \mathrm{MГц} \mathrm{(рисунки} 9$ та 10 , відповідно) густина струму при одновимірному розподіленні носить нерівномірний характер.

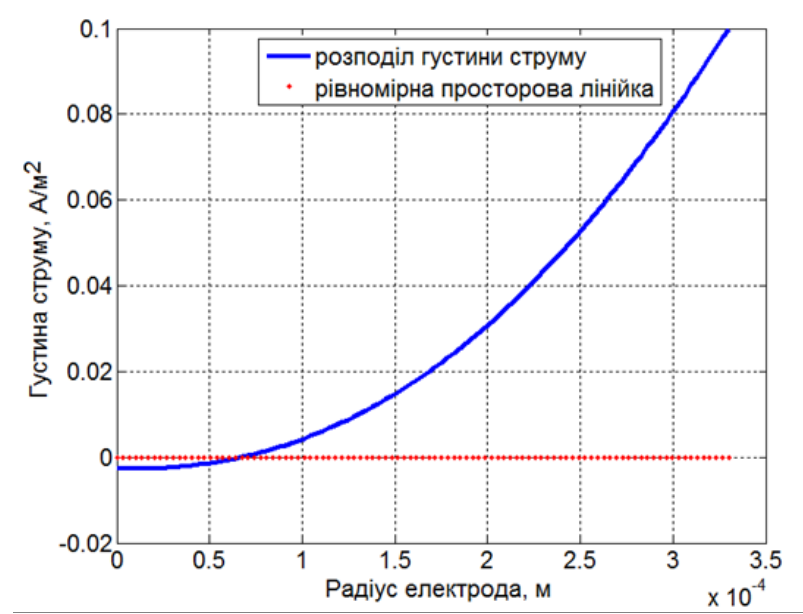

Рис. 9. Розподіл густини струму в мідному круглому електроді (частота 66 кГц).

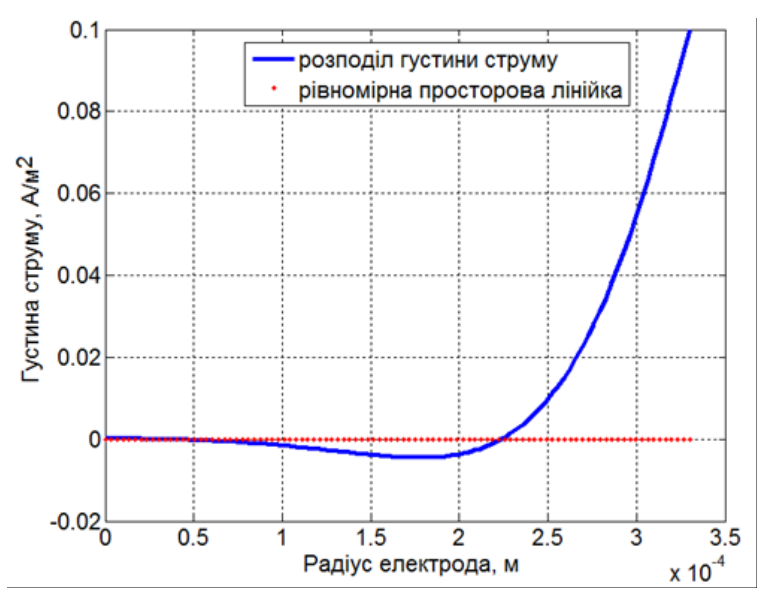

Рис. 10. Розподіл густини струму в мідному круглому електроді (частота 1 МГц).

Математична модель показує, що всередині круглого електрода струм високої частоти майже не тече.

При збільшенні частоти струму скінефект виражається в зменшенні товщини поверхневого шару по якому проходить змінний струм.

Розроблена математична модель по визначенню товщини скін-шару може застосовуватись для круглих провідників 3 різною електропровідністю (мідь, срібло, золото, алюміній, латунь та інш.) в широкому частотному діапазоні від 50 Гц (частота мережі живлення) до верхньої межі роботи високочастотних електрохірургічних джерел живлення - 4 МГц.

На рисунку 11 показано двовимірне розподілення густини струму в мідному круглому електроді для частоти змінного струму 1 МГц (радіус електрода 0,1 мм). 
Кольорова шкала: густина струму, $\mathrm{A} / \mathrm{M}^{2}$

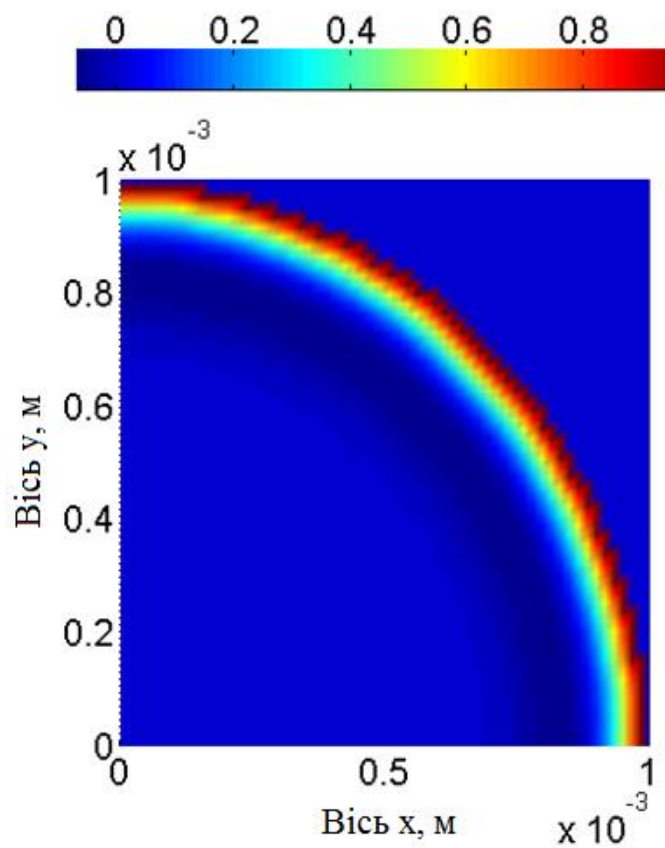

Рис. 11. Двовимірний розподіл густини струму в першій чверті мідного круглого електроду.

Також графічний редактор пакету Matlab дозволяє проаналізувати дану модель в тривимірному вигляді, де наочно видно, що струм високої частоти всередині електроду відсутній (рисунок 12).

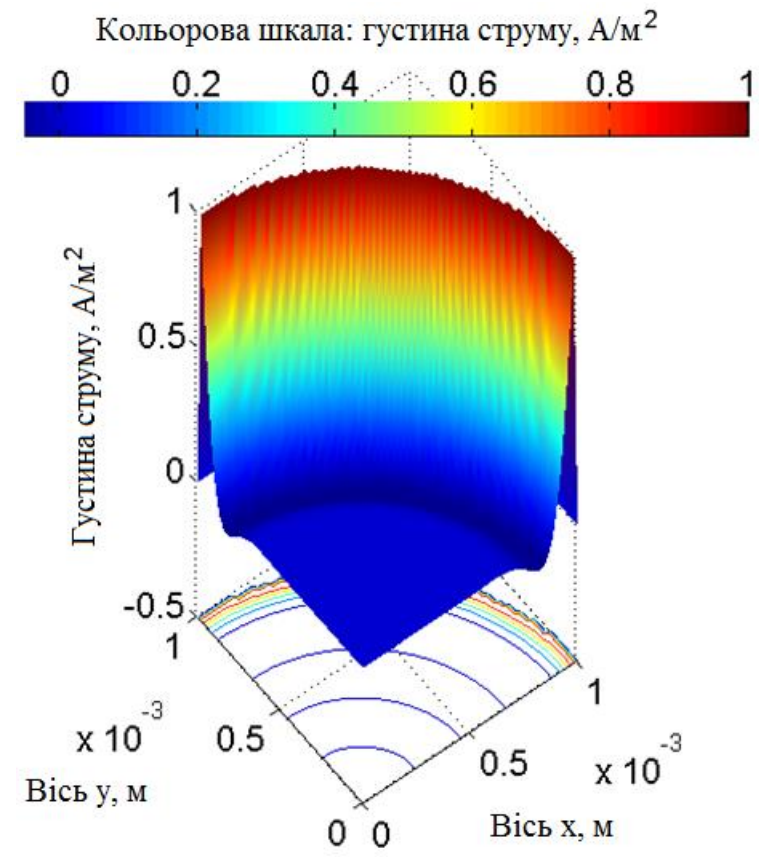

Рис. 12. Тривимірний розподіл густини струму в першій чверті мідного круглого електроду.

На рисунку 13 приведена тривимірна модель розподілу густини струму в мідному електроді 3 поперечним перерізом еліптичної форми, яка задається рівнянням

$$
\frac{x^{2}}{a^{2}}+\frac{y^{2}}{b^{2}}=1 \text {, }
$$

де a - велика піввісь (8 мм), b - мала піввісь (4 мм)

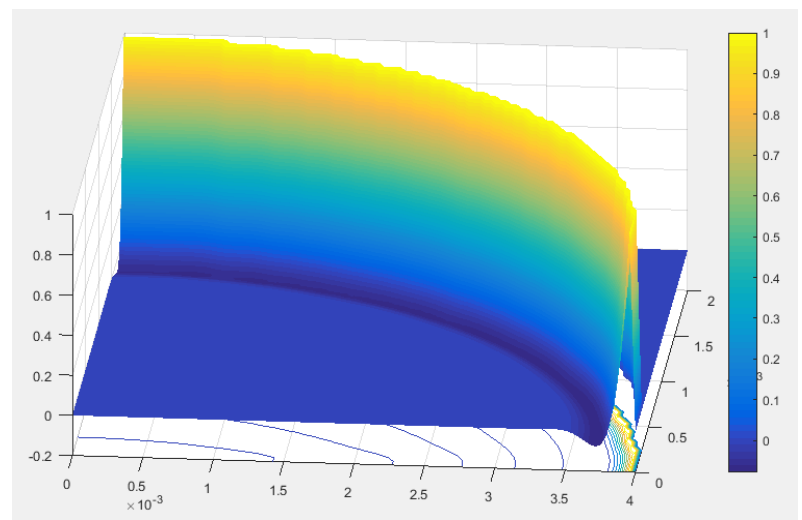

Рис. 13. Тривимірний розподіл густини струму в першій чверті електроду еліптичної форми.

На рисунках 14, 15 показані тривимірні моделі розподілу густини струму в мідному прямокутному електроді 3 поперечним перерізом 1X1 мм² на частотах 440 кГц та 1, 5 МГц відповідно.

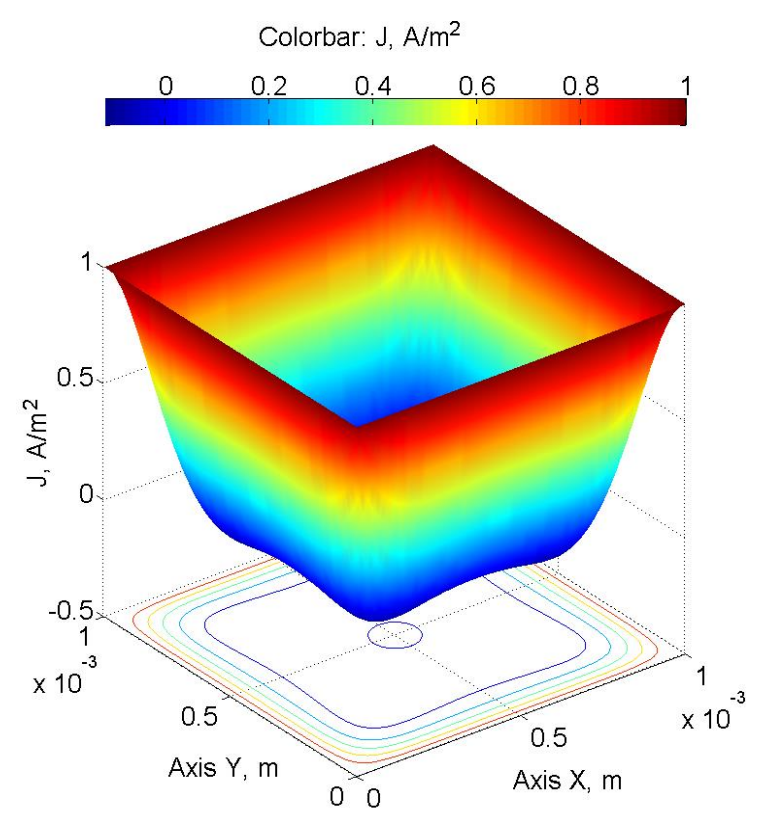

Рис. 14. Тривимірний розподіл густини струму в електроді прямокутної форми (частота 440 кГц). 


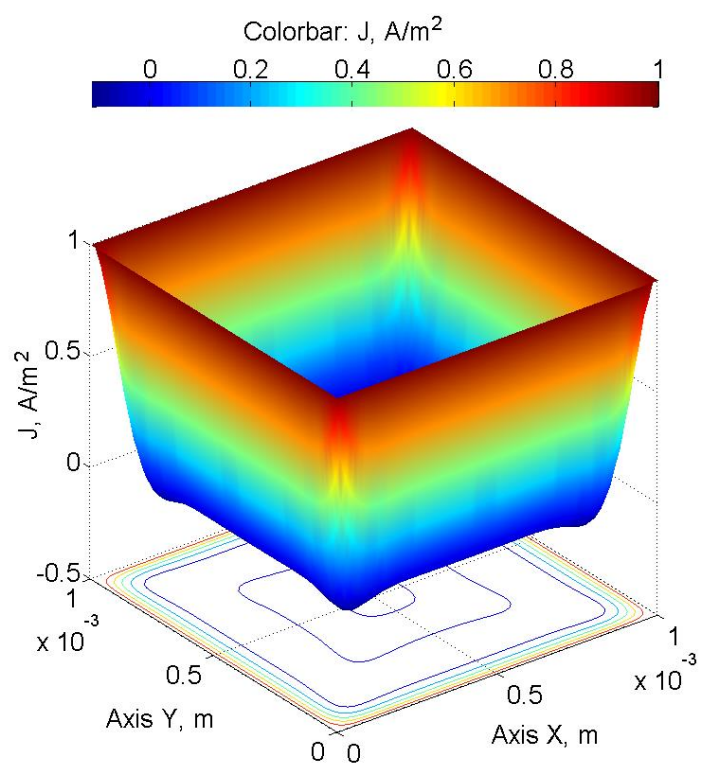

Рис. 15. Тривимірний розподіл густини струму в електроді прямокутної форми (частота 440 кГц).

Збільшити площу, яка проводить струм, можливо за рахунок збільшення загальної довжини зовнішнього периметра електрода та зміною форми його поперекового перерізу завдяки видаленню окремих ділянок електрода (профілювання).

Підвищити ефективність роботи електродів і тим самим знизити локальне перегрівання живих біологічних тканин та їх некроз, можливо за допомогою зміни форми поперечного перерізу електродів завдяки видаленню окремих ділянок (рисунок 16). Це призведе до більш рівномірного розподілу струму.

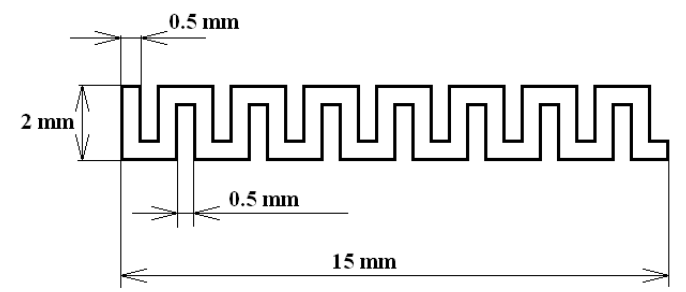

Рис. 16. Креслення електроду з збільшеною довжиною периметра.

Використовуючи симетрію поперечного перерізу електроду (рисунок 16), розподіл густини струму проаналізовано для ділянки мідного електроду 3 площею 2 х 2 мм $^{2}$ (рисунок 17). Експеримент реалізовано для частоти змінного струму 300 кГц.

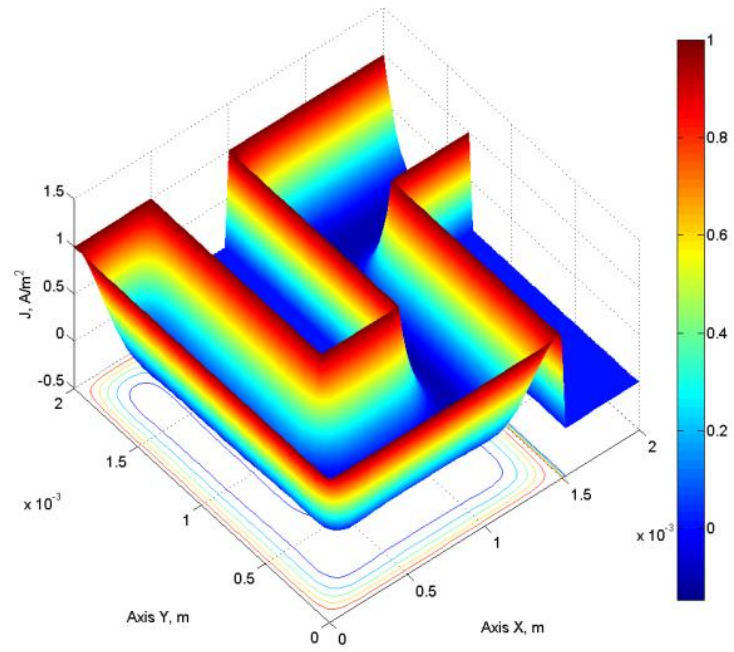

Рис. 17. Тривимірний розподіл густини струму в електроді з розвинутим периметром.

Наведені вище моделі детально описані в статтях та матеріалах міжнародних науково-практичних конференцій [12-15] .

Нові конструктивні форми електродів, які сприяють рівномірному розподілу високочастотного струму отримано патент на корисну модель [16].

\section{IV. ВИСНОВКИ}

Розроблені математичні моделі розподілу густини струму в електродах електрохірургічних інструментів з компактним та розвиненим поперечними перерізами, які дозволяють проаналізувати електромагнітні процеси, що відбуваються в них.

Створені моделі показують, що розподіл густини струму в електродах $\epsilon$ важливою складовою процесу високочастотного впливу на біологічні тканини, на відміну від існуючого погляду, що дію скін-ефекту можна не враховувати при моделюванні протікання високочастотного струму в електродах,

Запропоновані нові конструктивні форми електродів для високочастотної хірургії, які дають можливість рівномірно розподілити струм по їх контактним поверхням.

\section{ПЕРЕЛІК ПОСИЛАНЬ}

[1] Карпухин В. А. Исследование термоэлектрических характеристик артериол при биполярной электрокоагуляции / В. А. Карпухин, 3. А. Сидорова, О. А. Макарян // 13-я НТК «Медикотехнические технологии на страже здоровья» (Медтех - 2011): сб. тр. М.: МГТУ им. Н.Э. Баумана. - 2011. C. $149-151$.

[2] Белов С. В. Исследование принципов электрохирургических воздействий и разработка научных 
основ проектирования аппаратов и устройств для высокочастотной электрохирургии /С. В. Белов, автореф. дис. ... докт. техн. наук. // - М. : - 2004. -53 с.

[3] Лебедев А. В. Особенности применения теории контактной сварки металлов к сварке живых тканей / А. В. Лебедев, А. Г. Дубко // Технічна електродинаміка. - 2012. Вип. 2. - С. 187-192.

[4] Л.Д. Ландау, Е.М. Лифшиц. Теоретическая физика. Том VIII. Электродинамика сплошных сред. - М.: Наука. - 1982 г. $-623 \mathrm{c}$.

[5] Уманец, Н. Н. Ультраструктурные изменения сосудистой оболочки и сетчатки глаза кролика непосредственно после воздействия различных режимов высокочастотной электросварки биологических тканей [Текст] / Н. Н. Уманец, В. А. Науменко, Н. Е. Думброва, Н. И. Молчанюк, Р. Э. Назаретян // Журнал НАМН Украины. - 2014. - Т. 20, № 3. C. $359-364$

[6] Глухенький, А.И. Расчетная оценка составляющих импеданса цилиндрического проводника при их измерении на переменном токе [Текст] / А.И. Глухенький, А.А. Михаль // Технічна електродинаміка. - 2010. - № 1. - С. 15-22.

[7] Supan Tungjitkusolmun. Finite Element Analyses for a Study of Hepatic Cancer Tissue Destruction using Monopolar and Bipolar Radio-Frequency Ablation / INTERNATIONAL JOURNAL OF APPLIED BIOMEDICAL ENGINEERING VOL.2, NO.1 2009. P. 33-38. (English).

[8] Morton K. W. Numerical Solution of Partial Differential Equations /K. W. Morton, D. Mayers. // Cambridge University Press. SecondEdition. $-2005 .-279$ p.

[9] Каханер Д. Численные методы и программное обеспечение /Д. Каханер, К. Моулер, С. Неш.// - М. : Мир. 1998. -575 с.
[10] Лазарєв Ю. Ф. Довідник з MATLAB / Електронний навчальний посібник 3 курсового і дипломного проектування. - К.: НТУУ "КПІ", 2013. - 132 с.

[11] Zoya Popovic, Branko D. Popovic. Introductory Engineering Electromagnetics. Prentice Hall, 1999.-548p.

[12] Сидорець В.М., Дубко А.Г. Розподіл струму в електродах електрохірургічних інструментів при зварюванні біологічних тканин // Восточно-Европейский журнал передових технологий. - 2015. - №3. - C.24-28. DOI:10.15587/17294061.2015.43372.

[13] Сидорец В.Н., Дубко А.Г. Особенности анализа распределения тока высокой частоты в осесимметричных электродах электрохирургических инструментов // Електротехніка та електроенергетика. - 2015. - №2 - С. 42-47. [14] V. Sydorets, A. Lebedev, A. Dubko. Mathematical Modeling of the Current Density Distribution in a High-Frequency Electrosurgery // $201516^{\text {th }}$ International Conference on Computational Problems of Electrical Engineering (CPEE), Lviv, Ukraine. P. 215-217. DOI: 10.1109/CPEE.2015.7333379.

[15] V. Sydorets, A. Dubko, Increase of Efficiency of Electrosurgical Tools for Welding of Live Biological Tissues, 2nd International Conference on Intelligent Energy and Power Systems (IEPS - 2016), Kyiv, Ukraine (2016) 236-238.

[16] Патент України на корисну модель №117691. Активний електрод для високочастотної електрохірургії. Винахідники: Дубко А.Г., Чвертко Н.А., Сіленко А.К., Васильченко В.А. Опубл. 10.07.2017. Бюл. №13.

\section{МАТЕМАТИЧЕСКИЕ МОДЕЛИ РАСПРЕДЕЛЕНИЯ ПЛОТНОСТИ ТОКА ВЫСОКОЙ ЧАСТОТЫ В ЭЛЕКТРОДАХ С РАЗЛИЧНОЙ ФОРМОЙ ПОПЕРЕЧНОГО СЕЧЕНИЯ}

Дубко А.Г., с.н.с., к.т.н andreyies17@gmail.com

Отдел «Сварочные и родственные технологии в медицине и экологии» Института электросварки имени Е.О. Патона НАН Украины, г. Киев, Украина

Чвертко Н.A., с.н.с. , к.т.н chv@paton.kiev.ua

Отдел «Сварочные и родственные технологии в медицине и экологии» Института электросварки имени Е.О. Патона НАН Украины,

г. Киев, Украина

Лебедев А.В., проф., Д.т.н. biowelding@gmail.com

Факультет биомедицинской инженерии Национального технического университета «Киевский политехнический институт имени Игоря Сикорского», г. Киев, Украина

Подпрятов С.С., К.м.н. sspjdpr@gmail.com 
Киевская городская клиническая больница №1

г. Киев, Украина

Никитин В.А., студент

viktor070200@gmail.com

Факультет биомедицинской инженерии

Национального технического университета «Киевский политехнический институт имени Игоря Сикорского»,

г. Киев, Украина

Реферат - B среде математического пакета Маtlab проведен анализ распределения плотности высокочастотного тока в электродах электрохирургических инструментов. Представлены результаты расчетов одномерной и двухмерных задач, моделирующих толщину скин-эффекта в проводниках с различной формой поперечного сечения. Предложены новые конструктивные формы электродов для высокочастотной хирургии, которые дают возможность равномерно распределить ток по их контактным поверхностям.

Ключевые слова - токи высокой частоты, формы поперечного сечения электродов, математическое моделирование, скин-эффект, распределение плотности тока, Матлаб.

\section{MATHEMATICAL MODELS OF HIGH FREQUENCY DENSITY DISTRIBUTION IN ELECTRODES WITH DIFFERENT CROSS- SECTION FORMS}

Dubko A.G., s.n.s., Ph.D andreyies17@gmail.com Department of Welding and Related Technologies in Medicine and Ecology

E.O. Paton Electric Welding Institute,

Kiev, Ukraine

Chvertko N.A., s.n.s., Ph.D chv@paton.kiev.ua

Department of Welding and Related Technologies in Medicine and Ecology

E.O. Paton Electric Welding Institute,

Kiev, Ukraine

Lebedev O.V., Professor, D.Sc. in Engineering biowelding@gmail.com

Department of Biomedical Engineering National Technical University of Ukraine "Igor Sikorsky Kyiv Polytechnic Institute",

Kiev, Ukraine

Podpryatov S.S., Ph.D sspjdpr@gmail.com

Kyiv City Clinical Hospital №1,

Kiev, Ukraine

Nikitin V.O., student viktor070200@gmail.com

Department of Biomedical Engineering National Technical University of Ukraine "Igor Sikorsky Kyiv Polytechnic Institute",

Kiev, Ukraine

\footnotetext{
Abstract - In the environment of mathematical package Matlab the analysis of high frequency current density distribution in electrodes of electrosurgical instruments is made. The results of calculations of one-dimensional and two-dimensional problems are presented, which model the skin-effect thickness in conductors with different cross-sectional shape. New structural shapes of electrodes for highfrequency surgery are proposed, which make it possible to distribute the current evenly over their contact surfaces.
}

Keywords - high-frequency currents, electrode cross-sectional shapes, mathematical modeling, skin effect, current density distribution, Matlab. 